Original Bipolar 型 RFA 装置における焼灼のエンドポイントに関する検討

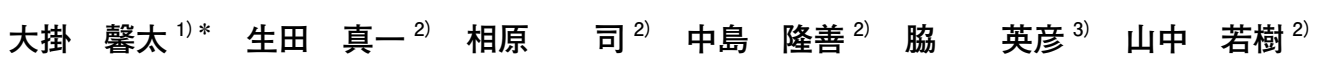

\title{
Experimental study on optimal endpoint for ablation using bipolar radiofrequency ablation system
}

\author{
Keita Ogake $^{1) *}$, Shinichi Ikuta ${ }^{2)}$, Tsukasa Aihara $^{2)}$, Takayoshi Nakajima $^{2)}$, Hidehiko Waki $^{3)}$, Naoki Yamanaka $^{2)}$
}

\begin{abstract}
An increase in tissue temperature or impedance (IMP) has each been used as endpoints for an ablation with monopolar radiofrequency induced thermotherapy (RFITT) system. In contrast, endpoint for an ablation using bipolar RFITT system is given by the total delivered energy that is determined depending on the types and number of applied needles (applicators). However, treatment endpoint defined by the delivered energy alone is associated with an increased risk for insufficient ablation. This experimental study verified optimal endpoint for bipolar ablation using ex-vivo porcine liver. We found that actual power output ("Power Effect" (PE)) and IMP were electrotechnically essential as indices for sufficient coagulation. In all experiments, sufficient coagulation was obtained when the procedure was finished after PE was below 5W and IMP between each electrode become higher than that of baseline. Using this endpoints, sufficient coagulation was achieved even when applicators were inserted with distance of $50 \mathrm{~mm}$, which was longer than the recommended distance by dosimetry table. In addition, with applicators distance of $13 \mathrm{~mm}$ or less, shorter ablation time and smaller delivered energy than their recommended values were available to obtain sufficient coagulation.
\end{abstract}

Key words: Bipolar radiofrequency ablation system, optimal endpoint for ablation, Coagulation zone, multipolar ablation, dosimetry table

Accepted on November. 2, 2015

1) 医療法人明和病院 ME センター =663-8186 兵庫県西宮市上鳴尾町4番31号

Clinical engineer of Meiwa General Hospital, Nishinomiya, Hyogo, Japan

Address: 4-31 Agenaruo-chou, Nishinomiya, Hyogo 663-8186, JAPAN

2) 医療法人明和病院 外科 $\quad$ T663-8186 兵庫県西宮市上鳴尾町4番31号

Department of Surgery, Meiwa General Hospital, Nishinomiya, Hyogo, Japan

Address: 4-31 Agenaruo-chou, Nishinomiya, Hyogo 663-8186, JAPAN

3) 医療法人明和病院 臨床検査科 =663-8186 兵庫県西宮市上鳴尾町4番31号

Department of Clinical Laboratory, Meiwa General Hospital, Nishinomiya, Hyogo, Japan

Address: 4-31 Agenaruo-chou, Nishinomiya, Hyogo 663-8186, JAPAN

* Reprint requests and correspondence to :

Keita OGAKE

Clinical engineer of Meiwa General Hospital

Address: 4-31 Agenaruo-chou, Nishinomiya, Hyogo 663-8186, JAPAN

E-mail: rinsyou kougakusitu@meiwa-hospital.com 


\section{【はじめに】}

これまで主流であったラジオ波焼灼療法（RFA）装置 はMonopolar型であり，焼灼エンドポイントは組織抵抗 (IMP) の上昇や設定温度（TEMP）到達であった ${ }^{1 \sim 3}$. 一方, 近年登場したBipolar型RFA装置 ${ }^{4}$ 8) $の$ 焼灼エン ドポイントは, 使用するバイポーラ電極（アプリケータ） のサイズと使用本数に応じた総エネルギー投与量で規定 されて抢り ${ }^{4,8)}$ ，ドジメトリーテーブル（DT）として提 供されている (Fig. 1)。しかし, 使用アプリケータの種 類や電極間距離がDTから逸脱した場合, 焼灼エンドポ イントに明確な基準は示されていない. 事実われわれは, 電極間距離がDT設定距離より離れた場合, 推奨エネル ギー量を投与しても円形状の凝固領域が得られず焼灼不 良となる症例を経験した。今回, 豚の摘出肝を用いて異 なるアプリケータ間距離で焼灼実験を行い，Bipolar型 RFAの適正なエンドポイントに関する知見を得たので
報告する．

\section{【方法】}

\section{Bipolar型RFA装置 $4,8,11$}

装置はOLYMPUS社のCelon Lab Powerを用いた。穿 刺針は同社のアプリケータ (Celon Pro Surge: OLYMPUS Medical, Tokyo, Japan）を使用し，通電中 は還流ポンプ (Celon Aqua flow III ; OLYMPUS Medical Instruments）を用いて室温の滅菌蒸留水を電極内に還 流させ冷却した。

本装置は焼灼する腫瘍サイズに応じて最大 3 本までア プリケータの同時使用が可能である。アプリケータを1 本のみ使用する場合はバイポーラ出力となり，2 本以上 用いる場合はマルチポーラ出力となる。アプリケータの サイズや使用本数は，焼灼する腫瘍の部位やサイズに応

じてDTを参考に選択する。焼灼のエンドポイントはDT

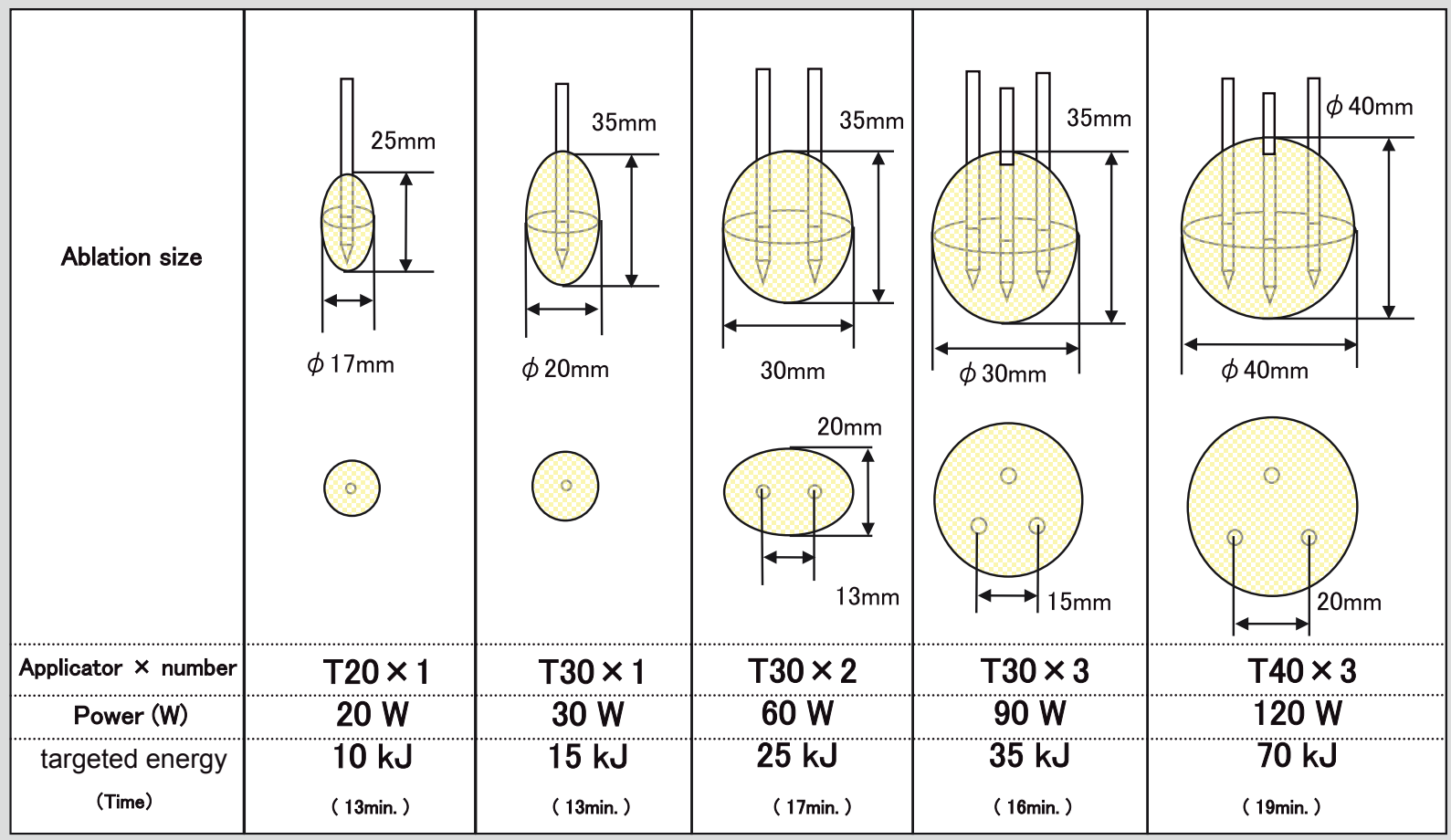

Fig. 1. Dosimetry Table

Size and number of the treatment applicators are selected mainly based on the size of tumor. The targeted energy from dosimetry table usually determine the endpoint of the procedure. 


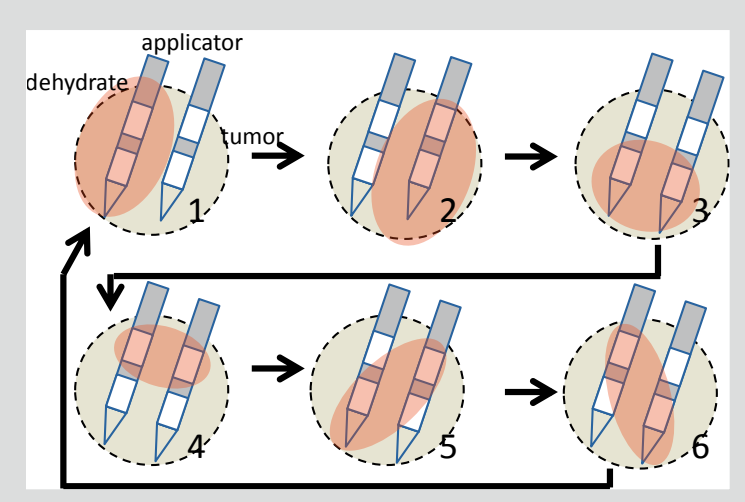

Fig. 2. Multipolar ablation

If two applicators are connected, the system works in multipolar mode. Under microprocessor control, the current flows between all possible electrode combinations resulting in bigger coagulation volumes, which allows the therapy of large tumors.
に定められた目標エネルギーが投与された時点に設定さ

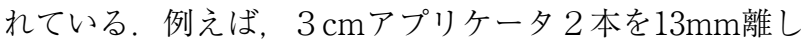
て穿刺した場合, 目標総投与エネルギーが $25 \mathrm{~kJ}$ となれば, 理論上 $30 \times 35 \mathrm{~mm}$ の焼灼領域が得られる (Fig. 1)。マル チポーラ出力の場合, 出力可能な 2 つの電極が 2 秒間ご とに切り替わり通電される。例えば 2 本のアプリケー夕 を使用した場合, 通電パターンは 6 パターンとなり（Fig. 2)，3 本使用した場合は15パターンとなる.

本装置は通電中の 2 電極間のIMPが計測され，モニ夕 リングが可能となっている。焼灼効果が得られIMPが上 昇した電極間では，組織の炭化を防止する自動機能 Resistance Controlled Automatic Power (RCAP) が働 く，RCAPが働いた電極間では，仮に設定出力が60Wで あっても実際に組織に投与される出力Power Effect $(\mathrm{PE})$ は5Wに低減する ${ }^{11)}$ 。今回, 焼灼中のIMPとPEをモニ夕 リングする為，本装置にCelon Power Monitorをインス トールしたパソコン（PC）を接続した (Fig. 3).

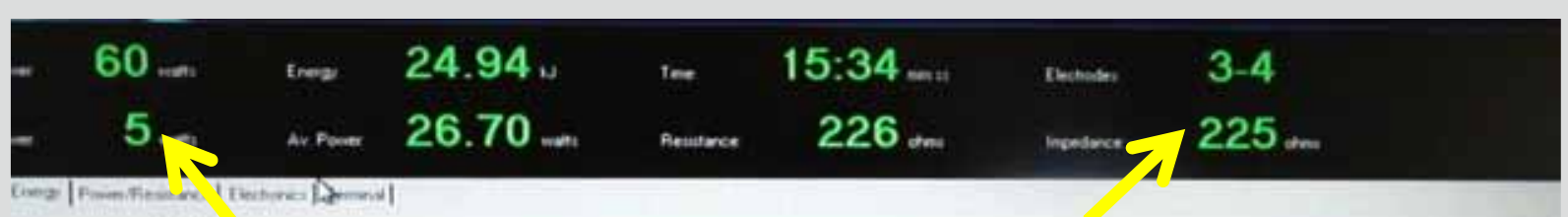

\section{Power Effect}

Impedance
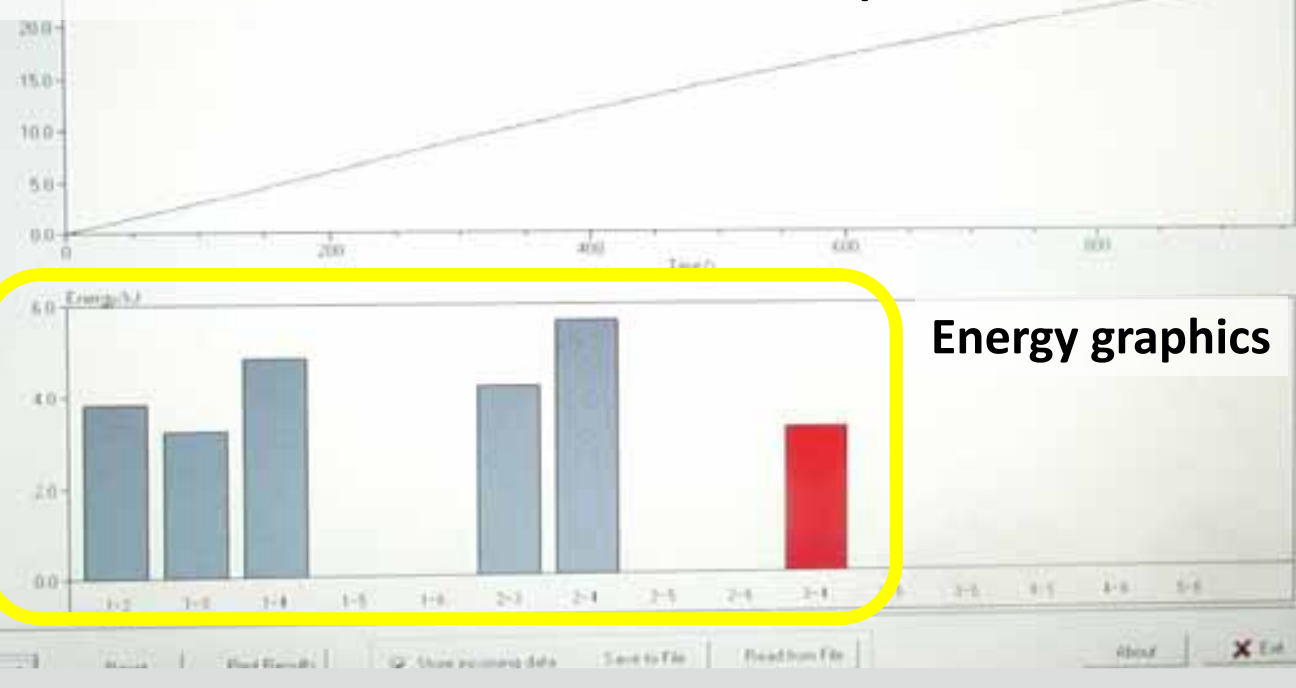

\section{Energy graphics}

\section{Fig. 3. The display of the monitoring program}

Online monitoring of energy delivery was easy and all the treatment variables (present and average Power Effect, Ablation Time, Impedance and Resistance) could be displayed online during the ablation, both graphically and numerically on the monitor. On the screen we monitored Power Effect and Impedance data. 


\section{2. 実験方法}

$3 \mathrm{~cm}$ 長のアプリケータ2本を使用し, 豚の摘出肝を用 いた通電実験を行った。アプリケー夕間距離をDT推奨 の $13 \mathrm{~mm}$ とした群（以下，13mm群）と50mmとした群 (以下, $50 \mathrm{~mm}$ 群) に分け, 各群それぞれ 3 回の通電実験 を行った. 初期出力は推奨の $60 \mathrm{~W} と$, 通電中はIMPと PEおよび，各電極間に投与された累積エネルギー量を PCモニターで観察した (Fig. 3). 通電のエンドポイン 卜は我々が電気工学的に考案した 6 パターンの電極間全 てのIMPが初期より上昇し，かつPEが5W以下に低下し た時点とした。通電終了後, 凝固領域 2 断面以上を検索 し最大焼灼範囲 (長径 $\times$ 短径) を計測した。

\section{【結果】}

\section{IMPおよびPEの推移}

焼灼開始直後，IMPは 6 パターンの電極間全てにおい
て徐々に低下傾向となったが，次第に上昇に転じた． PEは通電開始直後，6パターンの電極間全てが60Wを 示したが，時間経過とともに逐次5W以下に低下した。

\section{2. エネルギー量の推移}

投与エネルギー量は, 通電開始後しばらくの間は 6 パ ターンの電極間全てで均等に上昇した。焼灼効果が得ら れた電極間から逐次上昇は停止したが，最後まで上昇を 続けたのは 2 本のアプリケータの電極間であった。この エネルギー量の推移グラフから, 焼灼効果の得られた電 極間と未だ焼灼不十分な電極間が視覚的に把握可能で あった

\section{3. 焼灼範囲}

13mm群，50mm群各3回の焼灼実験いずれにおいても， 肉眼所見上アプリケータ間の焼灼不良域は認めなかった (Fig. 4)．各群の通電時間，エネルギー量，焼灼範囲を

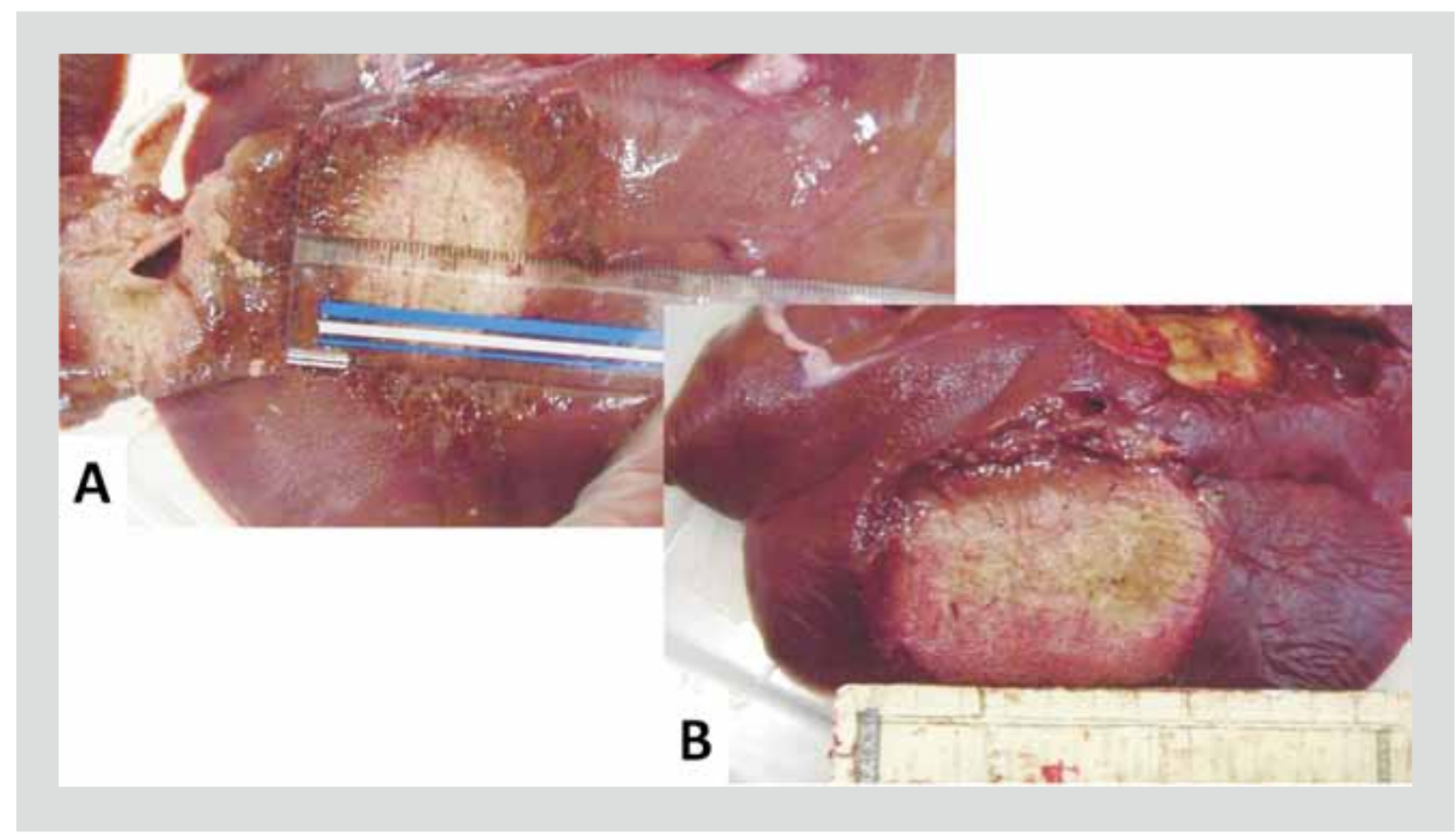

Fig. 4. Coagulation zones in the ex vivo porcine liver after multipolar RFA at $13 \mathrm{~mm}$ (A) and 50mm (B) applicator distance.

Complete tissue coagulation was grossly observed in all the experiments. Sufficient ablation was confirmed even when applicators were inserted at a distance of $50 \mathrm{~mm}$. 
Table 1. Parameters for multipolar ablation

\begin{tabular}{llll}
\hline Applicator distance & $\begin{array}{l}\text { Ablation time } \\
(\mathrm{min})\end{array}$ & $\begin{array}{l}\text { Delivered energy } \\
(\mathrm{kJ})\end{array}$ & $\begin{array}{l}\text { Ablated area } \\
(\mathrm{mm})\end{array}$ \\
\hline $13 \mathrm{~mm}$ & $8.55 \pm 2.28$ & $14.4 \pm 3.27$ & $(35 \pm 0.18) \times(30 \pm 0.47)$ \\
\hline $50 \mathrm{~mm}$ & $28.04 \pm 8.33$ & $45.6 \pm 13.60$ & $(75 \pm 0.47) \times(45 \pm 0)$ \\
\hline
\end{tabular}

Values are mean $\pm \mathrm{SD}(\mathrm{n}=3)$

（Table 1）に示した.

DTに従えば，13mm群において十分な焼灼範囲を得 るためには17分かけて25kJのエネルギー量を投与しなく てはならない（Fig. 1)．しかし，我々が考案したエンド ポイントを目標にすれば, DTよりも平均8.45分早く, $10.6 \mathrm{~kJ}$ 少ないエネルギー量で焼灼効果を得ることができ た。また，DTに従えば焼灼不良が懸念される50mm群 においても，肉眼的に十分な焼灼領域が得られた。

\section{【考察】}

Bipolar型RFA装置のDTは臨床経験を基にして作成さ れているが4.8)，DTに記載されたアプリケータの穿刺パ ターンは現在のところ5つのみである（Fig. 1). しかし 実際の穿刺では，DTに示された電極間距離を正確に保 ちつつアプリケータが完全に平行に刺入されることはむ しろ稀である。ささらに，本装置が臨床現場で多用される ようになると，例えば $2 \mathrm{~cm}$ 長と $3 \mathrm{~cm}$ 長のアプリケータ の組み合わせなどDTに記載のないパターンの穿刺を行 う場合もあろうと推測される。したがって，DTに示さ れた推奨投与エネルギーをエンドポイントに設定するの は自ずと限界がある。

われわれが医学中央雑誌で検索した限りではBipolar 型RFA装置のエンドポイントを見直した報告は涉猟で きなかった。 そこで，どのような指標を用いればDTか ら逸脱した条件下でも理論上十分な焼灼が可能となるか 検討し，今回適応したエンドポイントを考案した。

一般に，アプリケータ間の焼灼不良を回避する為には アプリケータ周囲を炭化させないことが肝要である。ア プリケータ周囲のIMPが急速に上昇すると組織の炭化が 起こり，RF電流の拡散が抑制され焼灼不良の原因とな る $^{12 \sim 14)}$. 現在のBipolar型RFA装置にはアプリケータ周 囲の炭化を予防するためいくつかの機能が備わってい る。一つは内部冷却式電極 ${ }^{12,13)}$ とパルス式RFA法 ${ }^{14)} に よ$
る通電であるが,この機能により高密度の電流を維持し つつ焼灼部位の熱を拡散させることができ，炭化を予防 することができる．また電極間IMPが上昇した際，出力 を自動的に最低レベルにまで低下させるRCAP機能があ $る^{15)}$. これらの機能が有効に作動した場合，モニター画 面に表示されるIMPはアプリケータ周囲の炭化に影響さ れず，電極間の焼灼状態を純粋に反映した ${ }^{1 \sim 3)} \mathrm{IMP}$ 判 断することができる．われわれはこのような装置の特性 を踏まえ, 各電極間の焼灼状況を電気工学的にモニタリ ングし，6パターンの電極間全てのIMPが上昇し，尚且 つRCAP機能が作動しPEが5Wに低下した時点を焼灼エ ンドポイントに設定した。その結果，アプリケータ間距 離が13mmの場合, DTの推奨エネルギー量よりも少な いエネルギー量で通電を終えても，肉眼的に十分な焼灼 領域を得ることができた。ささらにDT設定距離を大幅に 超えた $50 \mathrm{~mm}$ の距離で穿刺した場合でも同様な焼灼効果 が確認できた。

無論, 実臨床では標的病変と周囲組織や脈管との位置 関係, 背景肝機能などに配慮した通電時間の調節が不可 欠であり，単にIMPやPEのみを指標とした焼灼は合併 症を増す危険性を内在する。

また，今回の実験は摘出肝によるものであったため, 生体内での血流を考慮することができなかった，生体肝 では血流により組織が冷却されるため ${ }^{16,17)}$, 摘出肝より も焼灼範囲が小さくなること言われている ${ }^{18)}$ 。 よって今 回のエンドポイントを生体肝に適応した場合, 焼灼範囲 の縮小や焼灼時間の延長が考えられる.

しかし, われわれの提唱するエンドポイントは電気工 学的に理に適っていると考えられ, 今後更に知見が蓄積 され臨床現場で汎用されることを期待したい.

\section{【結語】}

1. Bipolar型RFA装置の焼灼エンドポイントは, 全電 
極間のIMPが上昇し，PEが5W以下になった時点で ある。

2.電極間距離がDT推奨距離より長い場合でも，上記
エンドポイントを目標に設定することで焼灼不良を

回避できる可能性がある.

\section{References}

1) John P. McGahan, MD, Shaun Loh, MD, MBA, Fernando J. Boschini, MD, Eric E. Paoli, BS, John M. Brock, BS, Wayne L. Monsky, MD, PhD, ChinShang Li, PhD, Maximizing Parameters for Tissue Ablation by Using an Internally Cooled Electrode, Radiology: Volume 256: Number 2-August 2010

2) S.Nahum Goldberg MD, G. Scott Gazelle MD MPH, Radiofrequency tissure ablation: Physical Principles and techniques for increasing coagulation necrosis, Hepatogastroenterology, 2001 Mar-Apr; 48(38): 359-67.

3) 大掛 馨太, 安井 智明, 相原 司, 生田 真一, 吉江 秀範, 飯田 洋也, 石倉 祥之, 原田 武志, 菊池 勝一, 柳 秀憲, 光信 正夫, 春日井 博志, 山中 若樹, ラジオ波焼灼中の組織インピーダンスの経時的波形変化が対極板熱傷の発生を反映していた症例の波形解析, 肝臟（0451-4203） 52 巻 6 号 Page361367 (2011.06)

4) Bernd B. Frericks, MD, Jorg P. Ritz, MD, Andre Roggan, PhD, Karl-Jogen Wolf, MD, Thomas Albrecht, MD, Multipolar Radiofrequency Ablation of Hepatic Tumors: Initial Experience1, Radiology 2005; 237:1056-1062

5) McGahan JP, Wei-Zhong G, Brock JM, Tesluk H, Jones CD. Hepatic ablation using bipolar radiofrequency electrocautery. Acad Radiol 1996;3:418422

6) Lee JM, Han JK, Kim SH, et al. A comparative experimental study of the in-vitro efficiency of hypertonic saline-enhanced hepatic bipolar and monopolar radiofrequency ablation. Korean J Radiol 2003;4:163-169

7) Mack MG, Straub R, Desinger K. MRguided interstitial bipolar RF thermometry: in-vivo evaluations and first clinical results [abstr]. Radiology 2000; 217(P):359

8) Olivier Seror, MD, PhD, Gise le N_Kontchou,MD, Medhat Ibraheem,MD, Yves Ajavon,MD, Corinne, Barrucand,MD, Nathalie Ganne,MD, Emmanuelle Coderc,MD, Jean Claude Trinchet,MD, Michel Beaugrand,MD, Nicolas Sellier,MDLarge ( $\geqq 5.0-\mathrm{cm}$ ) HCCs: Multipolar RF Ablation with Three Internally Cooled Bipolar Electrodes-Initial Experience in 26 Patients

9) Albrecht D, Germer CT, Isbert C, et al. Interstitial laser coagulation: evaluation of the effect of normal liver blood perfusion and the application mode on lesion size.Lasers Surg Med 1998;23:40-47.26

10) Vogl TJ, Mack M, Straub R, et al. Percutaneous interstitial thermotherapy of malignant liver tumors. Rofo 2000;172:12-22

11）バイポーラ RFA 電源装置システム CelonPOWER プロサージアプリケータ添付文書 2012 年 9 月 5 日（第一版）

12) Curley MG and Hamilton PS. Creation of Large Thermal Lesions in Liver using Saline-Enhanced RF ablation. Proc 19th Internal Conference IEEE/EMBS 1997; 2516-2519

13) Lorentzen T. A cooled needle electrode for radiofrequency tissue ablation: Thermodynamic aspects of Improved performance compared with conventional needle design. Acad Radiol 1996; 3: 556-563

14) Goldberg SN, Solbiati L,Hahn PF, Cosman E, Conrad J, Fogle R, and Gazelle GS. Large-Volume Tissue Ablation with Radiofrequency by Using a Clustered, Internally Cooled Electrode Technique: Laboratory and Clinical Experience in LiverMetastases. Radiology 1998; 209: 371-379

15) Goldberg SN, Stein M, Gazelle GS, Kruskal J, Clouse ME. Percuneous RF Tissure Ablation: Optimization of Pulsed-RF Technique to Increase Coagulation Necrosis. JVTR 1999

16) Goldberg SN, Hahn PF, Tanabe KK, Muller PR, Schima S, Arthanasoulis CA, Compton CC, Solbiati L, and Gazell GS. Percutaneous radiofrequency tissue ablation: Dose perfusion-mediated tissue cooling limit coagulation necrosis? JVIR 1998; 1998; 9: 101-111

17) Goldberg SN, Hahn PF,Halpern E, Fogle R, and Gazelle GS. Radiofrequency Tissue Ablation: Effect of Pharmacologic Modulation of Blood Flow on Coagulation Diameter. Radiology 1998; 209: 761-769

18) Siperstein AE, Roger SJ, Hansen PD, and Gitomirsky A. Laparoscopic thermal ablation of hepatic necroendocrine tumor metastases. Surgery 1997; 122: 1147-1155 